\title{
Response of the Thermal Conductivity as a Function of Water Content of a Burnt Mediterranean Loam Soil
}

\author{
Carles M. Rubio ${ }^{1,2}$, Xavier Úbeda ${ }^{3}$, Francesc Ferrer ${ }^{2}$ \\ ${ }^{1}$ Department Agri-Food Engineering and Biotechnology, Polytechnic University of Catalonia, Barcelona, Spain; ${ }^{2}$ Department Envi- \\ ronmental Biophysics and Soils, Lab-Ferrer Soils and Environmental Consulting, Cervera, Spain; ${ }^{3}$ Department Physical Geography, \\ University of Barcelona, Barcelona, Spain. \\ Email: carles.rubio@upc.edu
}

Received January 31 ${ }^{\text {st }}, 2012$; revised February $29^{\text {th }}, 2012$; accepted March $10^{\text {th }}, 2012$

\begin{abstract}
The purpose of this research is to explore the variability on the soil thermal conductivity $-\lambda$ - after a prescribe fire, and to assess the effects of the ashes on the heat transfer once it's were incorporated into the soil matrix. Sampling plot was located in the Montgrí Massif (NE of Spain). A set of 42 soil samples between surface and $5 \mathrm{~cm}$ depth was collected before and after the fire. To characterize the soil chemical and physical variables were analyzed. To determine the variability on the soil $\lambda$ a dry-out curve per scenario (before and after fire) was determined. SoilRho ${ }^{\circledR}$ method based on ASTM D-5334-08 which was validated by LabFerrer was used. Soil thermal conductivity has shown changes in their values. Indeed, in all moisture scenarios the values of soil $\lambda$ decreased after soil was burnt. The critical point in the relationship $\theta(\lambda)$ for the soil after fire which always was stronger than soil before to be burnt. Soil with "white" ashes showed a high thermal conductivity. An X-Ray diffractometry analysis allowed to clarify and to verify these results. To sum up, we could say that thermal conductivity presents changes when the scenario changes, i.e. before and after to be burnt. On the other hand, the volume of ashes incorporated on the soil increased the differences between no burnt and burnt soil, showing even some improvements on the heat transfer when water content started to govern the process.
\end{abstract}

Keywords: Thermal Properties; Soil Moisture; Prescribed Fire; Ashes; SoilRHO

\section{Introduction}

The impact of fire on soils can vary between highly beneficial, when the fire is not too intense and soil heating brief, to irreversible damage, which occurs during deeply penetrating heat pulses and long-term exposures [1,2]. Prescribed fires are used in Catalonia since 1999 as a tool, among others, for managing forested areas with large amounts of fuel in order to prevent high intensity fires. The Montgrí prescribed fire main objective was reduced the shrubland in an ancient and abandoned pine plantation. On the whole of the literature, many researchers have studied the variations on the chemical and physical properties on or above burnt soils, but there are other physical properties as are thermal properties that govern the heat flow transport inside the soil, and affect the aspects mentioned above. Because of the severity of the soil heating during a prescribed fire the impacts can be significant and serious. They include the formation of a hydrophobic layer on the surface of or within the soil, destruction of most of the organic material in the upper few centimeters of soil and the concomitant loss of soil aggregate stability [3], changes in soil $\mathrm{pH}$ and soil chem- istry, long-term differences in soil moisture amounts, increases in soil bulk density with accompanying decreases in soil porosity, therefore changes on soil structure $[2,4,5]$. Thus, when biomass on or above a soil surface burns, a heat pulse penetrates the soil. The resulting high soil temperatures can alter soil properties and kill roots and soil microbes [6].

On the other hand, changes in the soil thermal conductivity ( $\lambda$, a measure a soil's ability to conduct heat) are less obvious, but is not less significant because it is directly to many of the other fire included changes in the soil. Some of these changes would be changes in the structure, because soil thermal conductivity is strongly determined by soil structure [7], and soil composition [8,9], that occur whenever soil organic matter is combusted, therefore soil bulk density changes. Consequently, the purpose of this research is to explore the variability on the soil thermal conductivity $-\lambda$ - after a prescribed burn for a natural and typical Mediterranean limestone soil to laboratory scale. For achieving the main goal, it was splited into up three operative objectives; 1) to observe the relationship between soil thermal conductivity and 
water content, 2) to evaluate the influence of several percentages of ashes on the soil thermal conductivity, and 3) to determine which was the impact of the ashes on thermal conductivity when the ashes were incorporated into the soil matrix, taking account several moisture scenarios.

\section{Materials and Methods}

The study area is located in the north-eastern corner of the Iberian Peninsula in the coastal mountains of Catalonia, within the calcareous Montgrí Massif. The vegetation of this area is typically Mediterranean, composed of Pinus plantation (Pinus halepensis) with shrubland of Quercus coccifera, Cistus albidus, Rosmarinus officinalis and Pistacea lentiscus. At the time of the fire, the air temperature was $12.5^{\circ} \mathrm{C}$ with an air relative moisture about $60 \%$. In these conditions a prescribed fire was carried out. A set of 42 soil samples between surface and $5 \mathrm{~cm}$ depth was collected before and after the fire (UTM coordinates $\mathrm{x}: 514555 \mathrm{y}: 4659552)$. The size of the plot is $18 \times 4$ meters, with a quadrangular structure (see Figure 1). Soil samples were taken before, and just after the fire, from 42 points arranged in three transects and three crosses across the central transect.

The fire temperature of the soil surface was measured with a laser thermometer. To characterize the soil chemical and physical variables were analyzed. Particle-size distribution was determined using the wetting sieve method for 2000 to $50 \mu \mathrm{m}$ and a device by dispersion laser beams (Malvern Mastersizer/E) for particles smaller than $50 \mu \mathrm{m}$. Bulk density and porosity were determined from undisturbed sample volume. Calcium carbonate content was determined based on Bernard calcimeter [10], whereas the hygroscopic water content was determined by weight differences after drying the samples at $105^{\circ} \mathrm{C}$ during 24 hours the $\mathrm{pH}$ and conductivity was analysed following extraction with pure water (1:2.5), and measured with a $\mathrm{pH}$-meter and conductimeter [11]. The organic matter content was measured according to the sulfochromic oxidation method [12]. To determine the variability on the soil thermal conductivity $-\lambda$ - a dry-out curve (understood as the relationship between thermal conductivity and water content) was calculated $[13,14]$. The type of sample used for the experiment was a composed soil sample. 42 soil samples for each scenario, i.e. before and after prescribed burnt were used. The samples were wetted up with different quantities of deionized water, and packed until to

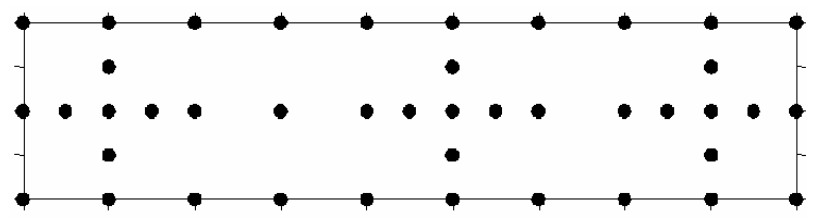

Figure 1. Sampling plot designed. Black points are sampling points. achieve the target bulk density into a soil column device. Water content was calculated by dried sample in the oven. To determine the thermal conductivity as a function of water content we used the SoilRho ${ }^{\circledR}$ method, which is based on ASTM D-5334-08. This methodology was developed according to the method described by Shiozawa and Campbell [15]. A SH-1 thermal sensor combined with KD2-Pro reader-logger allowed to obtain reliable and accuracy soil thermal conductivity values, thus obtaining a continuous large soil thermal data-set. In all cases, a set of 5 measures per moistured scenario $(n=30)$ were taken in both composed soil samples. The moisture process gave from air dried up to close to saturation.

The experimental design with ashes was performed on soil column devices, as well. For carrying out the ongoing research, several volumes of two types of ashes (white and black ashes) were used. The colour of ashes imply differences on the temperature reached on the soil surface, therefore, also imply differences in the own composition of ashes. The ashes were mixed with burnt soil on the percentages of $10 \%, 20 \% \cdots$, up to $90 \%$ in volume of ashes per volume of burnt soil. The differences on soil thermal conductivity for both types of ashes were evaluated only when soil was air dried.

For determining the thermal stability in the most critical case (90\% of ashes) a whole of dry-out curves were constructed. In this case, only took into account the higher percentage of two types of ashes (90\% white ashes and $90 \%$ black ashes). The dry out curves had 8 moistured scenarios with 5 thermal measures per scenario $(n=40)$. The moisture process gave from air dried up to close to saturation.

\section{Results and Discussion}

The soil from this plot in the Montgrí massif was classified according to USDA as loam textural class [16]. Mean bulk density was around $1.1 \mathrm{~g} \cdot \mathrm{cm}^{-3}$. The chemical and physical properties values before and after prescribed burnt were, respectively: mean total organic carbon content were about $14.7 \%$ and $17.2 \%$. The mean electric conductivity increased. On the other hand, the $\mathrm{pH}$ of the media did not show any change, and hygroscopic water content was similar, as well. All the values are the average of 42 samples taken before, and 42 samples taken after prescribed burnt. The values are showed in Table 1.

Respect to soil thermal conductivity $-\lambda$-, it showed changes in its values (Figure 2). Indeed, in all cases the values of the dry out curve for soil $\lambda$ decreased after soil was burnt than native soil. The critical point in the relationship $\theta(\lambda)$ always was stronger when soil samples were burnt than soil before prescribed fire, starting a critical reaction at $8 \%$ of water content for samples not burnt, and $6 \%$ of water content for burnt samples. Probably, this situation could be explained by the incorporation 
Table 1. Physical and chemical characteristics of the studied soil before and after fire. $\mathrm{OM}=$ organic matter content; $\mathrm{CaCO}_{3}=$ calcium carbonate content; $\mathrm{EC}=$ electrical conductivity and $\mathrm{Hw}=$ hygroscopic water content.

\begin{tabular}{lcc}
\hline Variables & Before Fire & After Fire \\
\hline Sand (\%) & 39.3 & 41.7 \\
Silt (\%) & 35.1 & 32.4 \\
Clay (\%) & 25.6 & 25.9 \\
E.C. $\left(\mu \mathrm{s} \cdot \mathrm{cm}^{-1}\right)$ & 330 & 520 \\
pH & 7.0 & 7.1 \\
O.M. $(\%)$ & 11.2 & 10.9 \\
$\mathrm{CaCO}_{3}(\%)$ & $<3$ & $<3$ \\
$\mathrm{Hw}(\%)$ & 1.8 & 1.9 \\
\hline
\end{tabular}

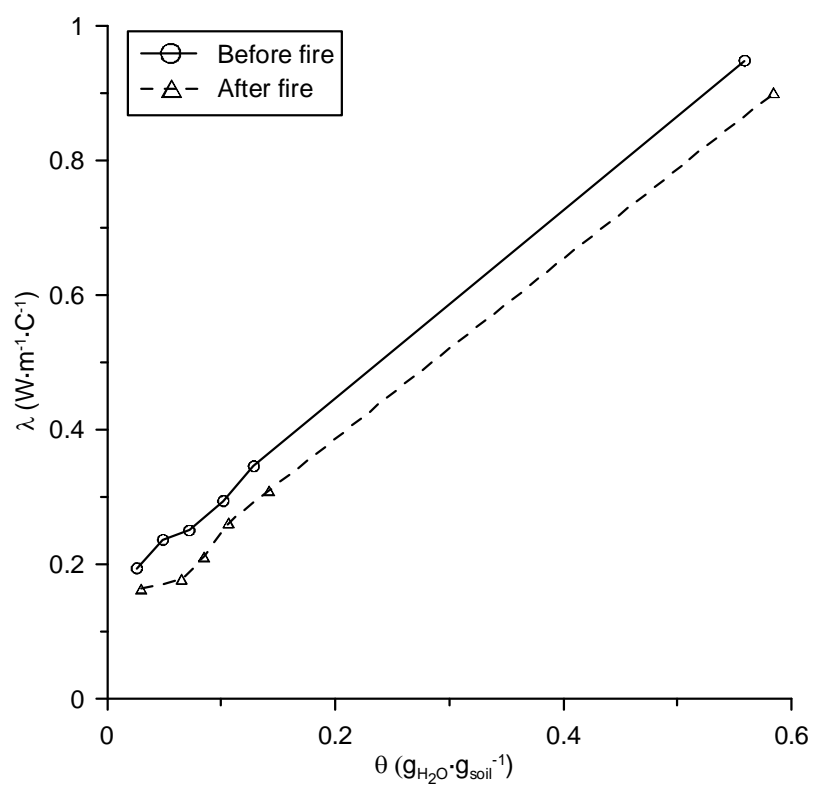

Figure 2. Dry-out curves of the relationship between thermal conductivity and gravimetric water content.

of burnt organic matter on the soil after prescribed fire, such that organic matter behaviour did not transmit well the heat pulse.

Also, the mean temperature values for the soil samples before and after fire during the experiment were about $21.5^{\circ} \mathrm{C}$ and $18.5^{\circ} \mathrm{C}$, respectively. The difference between both values did not affect the soil thermal properties measurements. On the other hand, the coefficient of variation of the thermal conductivity measures indicated that the values were between $0.4 \%$ and $2.2 \%$ for not burnt soil, and $0.3 \%$ and $1.7 \%$ for burnt soil. Therefore, the values were considered as acceptable, and very homogeneous.

Finally, a new experiment using the black and white ashes found out over the soil surface after fire was carried out. After the prescribed fire a different quantity of ash patches were found out.

Some of the patches were black ashes where the tem- perature of the fire was lower, and other patches were white ashes where the temperature of the fire was higher (around $600^{\circ} \mathrm{C}$ ). The new test was used to find differences out between two types of ashes. The soil samples after fire was used to amend and to repack with different quantities of black ashes in volume percentage of soil $(0 \%$, $10 \%, 20 \%, 30 \% \cdots 100 \%$ ), and maintaining a similar bulk density. The same test was performed with white ashes.

The relationship between bulk density and porosity using burnt soil and different ashes (black and white) is showed in Figure 3. The linear relation between both variables means a well-compacted soil samples, and a decreasing pattern of the macro-porosity when bulk density increase, as well. In any case, two well-defined groups of samples were determined. The soil mixture with black ashes presented less bulk density values than soil with white ashes, which it presented a lower porosity. [3] presented the results about differences in the bulk density for a two soils after fire. Their conclusions were focused in some changes about bulk density, but only within the top section $(0.05 \mathrm{~m})$. This fact would evidence the incorporation of a certain quantity of ashes in the few top centimeters of the soil surface, and it would involve a less bulk density than below $0.05 \mathrm{~m}$, such that the compactation effects are limited to upper $0.05 \mathrm{~m}$ only [3].

Figure 4, presents different quantities on percentages of two types of ashes mixture with burnt soil, where soil thermal conductivity was measured. The white ashes (dot line) always shown a higher thermal conductivity, meanwhile soil with black ashes was a lower $\lambda$. Probably, this fact would be attributed by the large organic carbon content that was not burned during the prescribed fire [17], such that the organic carbon content has a low thermal

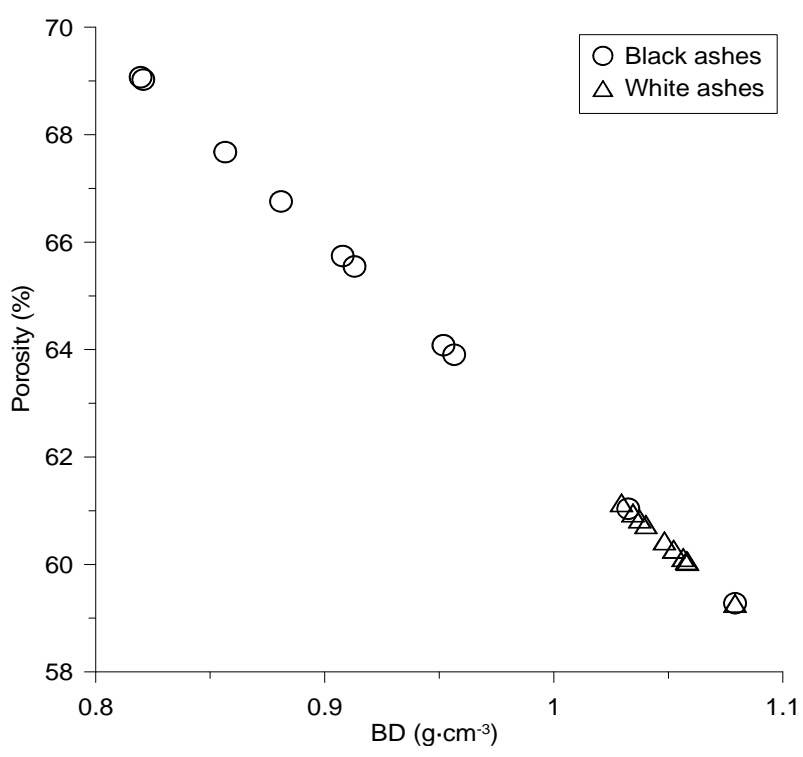

Figure 3. Relationship between bulk density and porosity for a burnt soil mixture with two different types of ashes. 


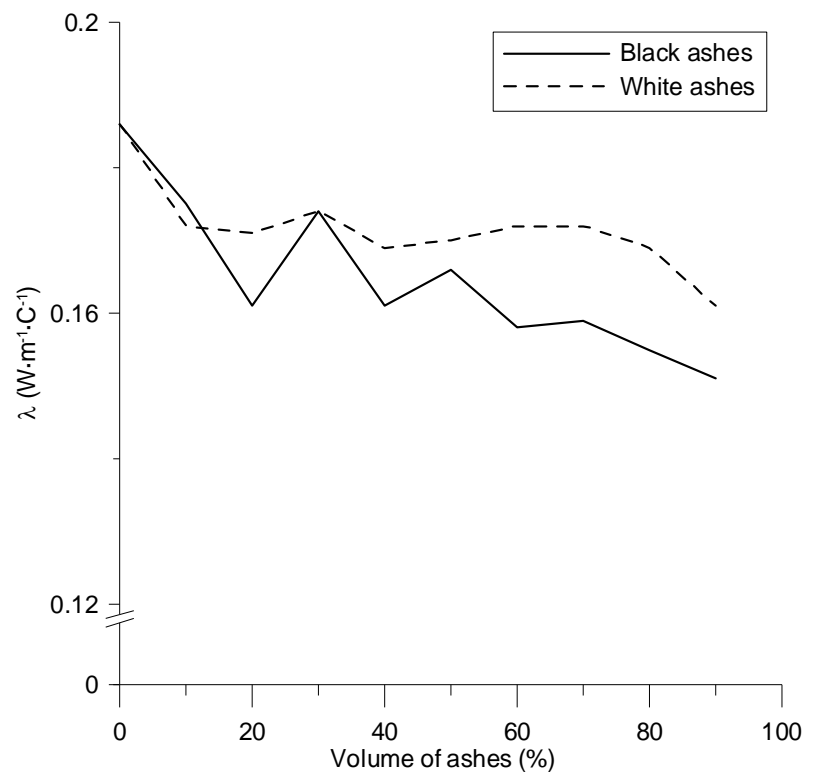

Figure 4. Effects of the different ashes on soil thermal conductivity for a burnt soil.

conductivity, and bigger particle size than ashes [18]. Thus, when organic matter content increase exhibit a decrease of soil $\lambda$ [19]. However, the fine particle size of the white ashes improved the target bulk density, therefore it contributed to improve the soil thermal conductivity values, except in the two peaks relatives to $30 \%$ and $50 \%$, where the quantity of black ashes decreased, it became similar thermal conductivity values than white ashes. On the whole of the experiments, the coefficient of variation indicated that the dispersion was less of $2.4 \%$ for whites ashes, and
$2.9 \%$ for black ashes. Therefore, the overall data set was acceptably homogeneous.

During a burn one may expect changes in soil biota, soil chemistry, and soil minerals [5]. To verify in detail the differences between both soil samples (before and after burnt), an X-ray difractometry was performed. Figure 5 , shows the results of the analysis. The soil before fire (black line) presented a less quartz than soil after fire, however, exist traces of mica muscovite, which it disappear when soil was burnt.

The values of quartz element increased substantially after burnt, probably the plagioclase were unstructured when temperature rose over $500^{\circ} \mathrm{C}$, releasing the quartz and some cations. In this case, the electric conductivity of the soil would be increased, such as indicated the Table 1.

Eventually, in Figure 6, can observe the relationship between thermal conductivity as a function of water content for a soil sample after burnt with $90 \%$ of volume of ashes (white and black ashes).

Clearly, differences exist between white and black ashes when these were incorporated into the soil matrix. In all cases, especially when the soil was closed to saturation the differences were higher. An acceptable explanation could be splited as follows: 1 ) white ashes presented a fine particle size, hence it increased the water film around the particle, and increased the bulk density as well, reducing the air filled inside the samples. Therefore, a rather high compaction than black ashes involved a better heat transfer; 2) mica muscovite presents dielectric properties, therefore it is a good resistivity material. When mica muscovite disappeared, the thermal conductivity increased.
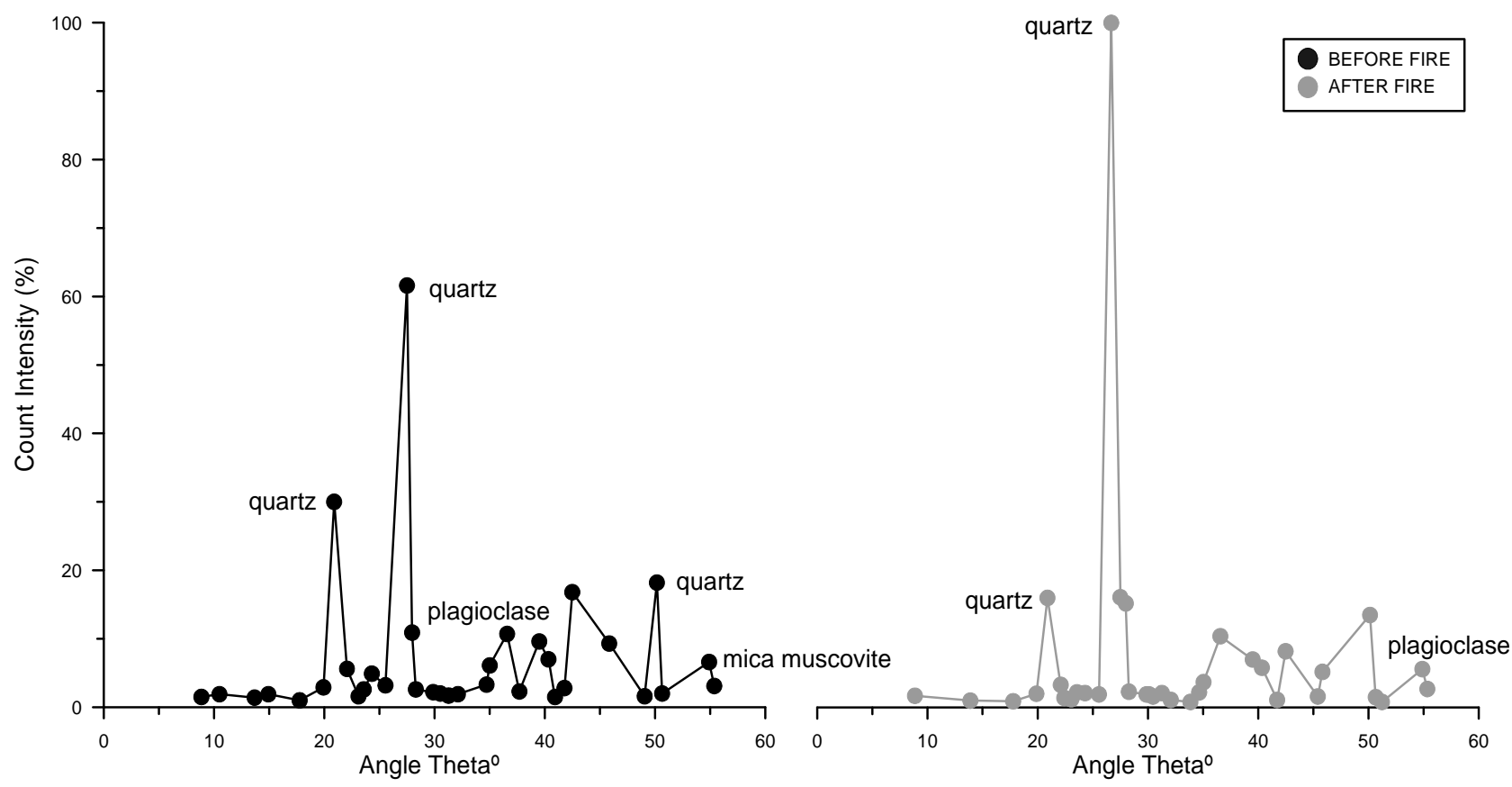

Figure 5. X-Ray difractometry analysis for soil samples before and after prescribed fire. 


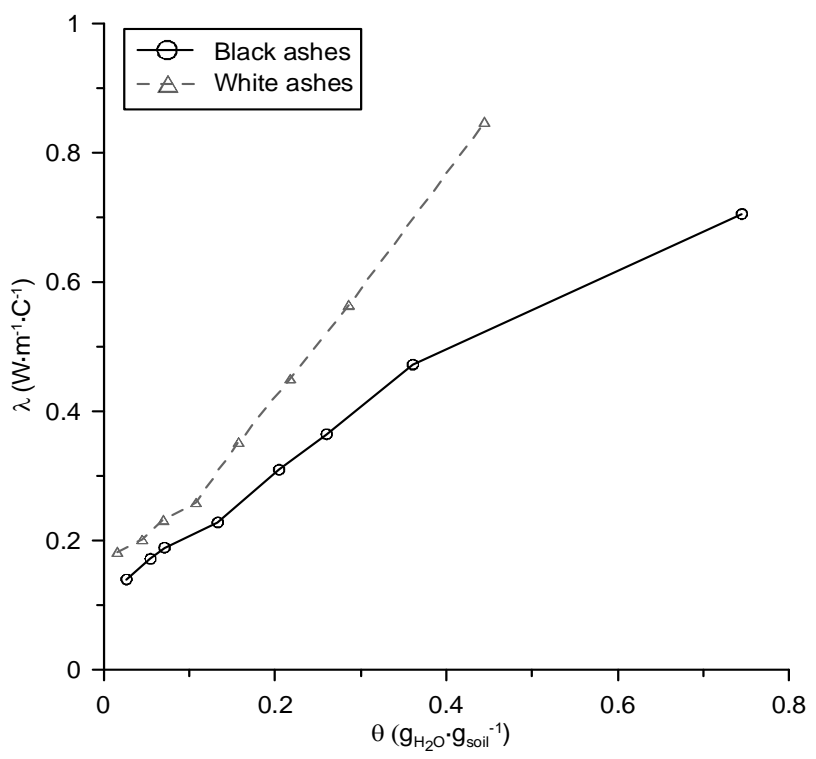

Figure 6. Dry-out curves of the relationship between thermal conductivity and gravimetric water content, when different types of ashes (white and black) were incorporated into the soil matrix.

Finally, note that the particle size of the black ashes were large than white ashes, and also the organic carbon content did not works well when the heat flux transfer was necessary. The measurements of the thermal conductivity of ashes revealed that $\lambda$ presented a high influence due to water film around the ashes $[3,20]$.

\section{Conclusion}

As summary, we could say that thermal properties can present changes when the scenario changes, i.e. before and after a prescribed fire. Soil after fire always presented a less thermal conductivity, and therefore a less thermal diffusivity, and volumetric specific heat capacity. On the other hand, when the ashes provoked by the fire were incorporated to the soil, the white ashes, which are poorer in organic carbon content, provided a better heat flow transfer. Also, the particle size was relevant in the retention water content. Therefore, when soil is burned its thermal properties change, and a natural or anthropic addition of ashes, especially white ashes, could improve the conductance of the heat flux into the soil, improving the soil bulk density, and water retention content as well.

\section{Acknowledgements}

The research was founded by Lab-Ferrer Soils and Environmental Consulting Center and University of Barcelona. Likewise, we want to mention the agreements between LabFerrer and the Department of Agri-Food Engineering and Biotechnology of the Universitat Politècnica de Catalunya. We thank the GRAF team for the fieldwork support during the prescribed fire.

\section{REFERENCES}

[1] L. F. DeBano, D. G. Neary and P. F. Ffolliott, "Fire's Effects on Ecosystems,” JohnWiley \& Sons, New York, 1999.

[2] L. F. DeBano, D. G. Neary and P. F. Ffolliott, "Chapter 2: Soil Physical Properties,” In: D. G. Neary, K. C. Ryan and L. F. DeBano, Eds., Wildland Fire in Ecosystems: Effects of Fire on Soil and Water, United States Department of Agriculture, Ogden, 2005, pp. 29-51.

[3] W. J. Massman, J. M. Frank and N. B. Reisch, "LongTerm Imapcts of Prescribed Burns on Soil Thermal Conductivity and Soil Heating at a Colorado Rocky Mountain Site: A Data/Model Fusion Study,” International Journal of Wildland Fire, Vol. 17, No. 1, 2008, pp. 131-146. doi:10.1071/WF06118

[4] E. L. Huffman, L. H. MacDonald and J. D. Stednick, "Strength and Persistence of Fire-Induced Soil Hydrophobicity under Ponderosa and Lodgepole Pine, Colorado Front Range," Hydrological Processes, Vol. 15, No. 15, 2001, pp. 2877-2892. doi:10.1002/hyp.379

[5] D. G. Neary, K. C. Ryan, L. F. DeBano, J. D. Landsberg and J. K. Brown, “Chapter 1: Introduction,” In: D. G. Neary, K. C. Ryan and L. F. DeBano, Eds., Technical Report RMRS-GTR-42, United States Department of Agriculture, Ogden, 2005, pp. 1-17.

[6] G. S. Campbell, J. D. Jungbauer, W. R. Bidlake and R. D. Hungerford, "Predicting the Effect of Temperature on Soil Thermal Conductivity," Soil Science, Vol. 158, No. 5, 1994, pp. 307-313.

[7] O. T. Farouki, “Thermal Properties of Soils,” Trans Tech Publications, Clausthal-Zellerfeld, 1986.

[8] D. A. DeVries, “Thermal Properties of Soils,” In: W. R. van Wijk, Ed., Physics of Plant Environment, John Wiley \& Sons, New York, 1963, pp. 210-235.

[9] G. S. Campbell and J. M. Norman, “An Introduction to Environmental Biophysics,” 2nd Edition, Springer-Verlag, NewYork, 1998.

[10] S. I. M.Skinner, R. L. Halstead and J. E. Brydon, "Quantitative Manometric Determination of Calcite and Dolomite in Soils and Limestones," Canadian Journal of Soil Science, Vol. 39, No. 2, 1959, pp. 197-204. doi:10.4141/cjss59-025

[11] Ministerio de Agricultura, Pesca y Alimentación, "Métodos Oficiales de Análisis Tomo III, Secretaría General Técnica," M.A.P.A., Madrid, 1986.

[12] A. Walkley and I. A. Black, “An Examination of the Degtjareff Method for Determining Soil Organic Matter and a Proposed Modification of the Chromic Acid Titration Method," Soil Science, Vol. 37, No. 1, 1934, pp. 2938. doi:10.1097/00010694-193401000-00003

[13] C. M. Rubio, R. Josa, J. M. Villar, F. Fonseca and F. Ferrer, "Development of Laboratory Analytical Procedures to Determine Thermal Properties in Soils," Proceedings of III International Meeting of the European Confederation of Soil Science Societies EUROSOIL, Vienna, 28 August 2008, p. 308.

[14] C. M. Rubio, R. Josa, D. R. Cobos, C. S. Campbell and F. Ferrer, "Hysteretic Behaviour of Thermal Properties on 
Porous Media Advances in Studies on Desertification,” University of Murcia, Murcia, 2009.

[15] S. Shiozawa and G. S. Campbell, "Soil Thermal Conductivity,” Remote Sensing Reviews, Vol. 5, No. 1, 1990, pp. 301-310.

[16] Soil Survey Staff, "Keys to Soil Taxonomy,” 8th Edition, US. Government Printing Office, Washington DC, 1998.

[17] N. H. Abu-Hamdeh and R. C. Reeder, "Soil Thermal Conductivity: Effects of Density, Moisture, Salt Concentration and Organic Matter," Soil Science Society of America Journal, Vol. 64, No. 4, 2000, pp. 1285-1290. doi:10.2136/sssaj2000.6441285x
[18] T. F. Wall, S. P. Bhattacharya, D. K. Zhang, R. P. Gupta and X. He, "The Properties and Thermal Effects of Ash Deposits in Coal-Fired Furnaces," Progress in Energy and Combustion Science, Vol. 19, No. 6, 1993, pp. 487-504.

[19] K. Noborio and K. J. McInnes, "Thermal Conductivity of Salt Affected Soils,” Soil Science Society of America Journal, Vol. 57, No. 2, 1993, pp. 329-334. doi:10.2136/sssaj1993.03615995005700020007x

[20] L. R. Iverson and T. F. Hutchinson, "Soil Temperature and Moisture Fluctuations during and after Prescribed Fire in Mixed-Oak Forest, USA,” Natural Areas Journal, Vol. 22, No. 4, 2002, pp. 296-304. 